\title{
SUSCEPTIBILITY PROFILE OF Salmonella AGAINST THE ANTIBACTERIAL ACTIVITY OF PROPOLIS PRODUCED IN TWO REGIONS OF BRAZIL
}

\author{
ORSI R. O. (1), SFORCIN J. M. (2), RALL V. L. M. (2), FUNARI S. R. C. (1), \\ BARBOSA L. (3), FERNANDES JR A. (2)
}

(1) Department of Production and Animal Exploration, School of Veterinary Medicine and Animal Husbandry, São Paulo State University (UNESP), Botucatu, São Paulo, Brazil; (2) Department of Microbiology and Immunology, Biosciences Institute, UNESP, Botucatu, São Paulo, Brazil; (3) Department of Biostatistics, Biosciences Institute, UNESP, Botucatu, São Paulo, Brazil.

ABSTRACT: Propolis antibiotic action has been widely investigated. This assay was carried out in order to observe the in vitro antibacterial activity of propolis against Salmonella enteritidis isolated from food and Salmonella typhimurium isolated from human infections. Propolis was collected by Apis mellifera in two regions of Brazil (Mossoró, Rio Grande do Norte State; and Urubici, Santa Catarina State). Both strains survival percentage decreased with time of incubation in Ethanolic Extracts of Propolis (EEP), demonstrating bactericidal effect after 24 hours. It was also observed that EEP from Mossoró was more effective than that from Urubici. The control of the propolis solvent - $70 \%$ ethanol - was less effective than EEP, showing only a bacteriostatic effect. We can conclude that propolis shows an activity against Gramnegative bacteria that varies according to the geographical region where it was collected by bees.

KEY WORDS: propolis, susceptibility profile, Salmonella, food, infection.

\section{CORRESPONDENCE TO:}

R. O. ORSI, Departamento de Produção e Exploração Animal, Faculdade de Medicina Veterinária e Zootecnia, Universidade Estadual Paulista (UNESP), Distrito de Rubião Junior, S/N, 18618-000, Botucatu, São Paulo, Brasil.

Email: orsi@fca.unesp.br 


\section{INTRODUCTION}

Propolis, a natural product collected by Apis mellifera from plant exudates, shows a complex chemical composition (1). Its biological properties - such as antibacterial (14), antiviral (2), antifungal (5), among other activities - have attracted the researchers' interest.

Many authors have demonstrated propolis antibacterial activity against Enterococcus sp, Escherichia coli (6), and, especially, Staphylococcus aureus (8). Reports have pointed out propolis efficient activity against Gram-positive bacteria and limited action against Gram-negative bacteria $(7,14)$.

Its biological properties may vary according to different plant sources (9). In Brazil, there are many plants that could be visited by bees as sources of propolis, whose chemical composition may differ depending on the geographic location.

Salmonella has been one of the most frequent agents that cause food contamination and human infections all over the world. It has become a significant worldwide public health problem (17). Every year, a thousand cases of Salmonella infection are reported in the United States, such as diarrhea, fever, and abdominal cramps (4). In Brazil, Salmonella contamination is very common (10).

The aim of this study was to compare the antibacterial activity of ethanolic extract of propolis produced in two different regions of Brazil against Salmonella enteritidis (isolated from food) and Salmonella typhimurium (isolated from human infections).

\section{MATERIALS AND METHODS}

\section{Propolis}

Propolis was collected by Apis mellifera in two different regions of Brazil: Urubici Santa Catarina State, South of Brazil; and Mossoró - Rio Grande do Norte State, Northeast of the country. Propolis samples ( $30 \mathrm{~g}$ of propolis, and $70 \%$ ethanol to a final volume of $100 \mathrm{ml}$ ) were ground and extracted in absence of bright light, at room temperature; after a week, extracts were filtered (14).

\section{Bacterial strains}

A bacterial strain was isolated from contaminated food from Botucatu city and identified as Salmonella enteritidis. A human infection strain was obtained at the University Hospital, Botucatu School of Medicine, São Paulo State University 
(UNESP), and identified as Salmonella typhimurium. Both strains were identified at the Adolpho Lutz Institute, São Paulo, Brazil.

\section{Minimal inhibitory concentration (MIC) of propolis and survival curve}

The Minimal Inhibitory Concentration (MIC) of propolis was previously determined as $10.0 \%(\mathrm{v} / \mathrm{v})$ to both propolis samples in culture medium (Mueller Hinton Agar), according to the National Committee of Clinical Laboratory Standard guidelines (12). The MIC of $70 \%$ ethanol - used as a control of the solvent effect - was $12.6 \% \mathrm{v} / \mathrm{v}$. The survival curve was determined in order to observe the incubation period responsible for propolis antibacterial activity. Thus, Salmonella strains, in a concentration of approximately $10^{6}$ Colony Forming Units (CFU), were inoculated in Brain Heart Infusion plus propolis, corresponding to the MIC previously obtained to both samples. After $1.5,3,6,9,14$, and $24 \mathrm{~h}$ incubation $\left(37^{\circ} \mathrm{C}\right)$, aliquots of each culture were removed and platted on Mueller Hinton Agar by the Pour Plate Method. Plate counts were carried out after 24 hours incubation and the survival percentage was calculated (14).

\section{Statistical Analysis}

Friedman repeated measures analysis of variance was used to examine the treatment effect on the Salmonella strains survival curve, according to the incubation period in medium plus propolis. Chi-square test was used and the probability of 0.05 was considered significant (18).

\section{RESULTS AND DISCUSSION}

We verified that both propolis samples showed a bactericidal activity against Salmonella enteritidis (Figure 1A) and Salmonella typhimurium (Figure 2A), showing a remarkable inhibitory effect after 14 hours and bactericidal effect after 24 hours incubation (Figure 1B; Figure 2B). We also observed that 70\% ethanol showed only bacteriostatic activity on both strains during the 24 hours incubation.

Propolis has been widely used in folk medicine because of its biological and therapeutic activities such as microbicidal action (2). Its properties were verified against Staphylococcus aureus, Enterococcus sp, Escherichia coli $(5,8)$, and Pseudomonas aeruginosa (14). 
Salmonella growth was only inhibited by higher propolis concentration $(10.0 \% \mathrm{v} / \mathrm{v})$, what is in accordance with the results in literature $(7,14)$, showing propolis limited action on Gram-negative bacteria. The bacteriostatic activity of $70 \%$ ethanol on both strains suggested that propolis action was only due to its components.

A possible explanation for propolis action mechanism may be the fact that one or some of its constituents caused a significant inhibition of bacterial mobility, besides ion permeability alteration on the inner bacterial membrane (11). Takaisi-Kikuni and Schilcher (15) proposed that ethanolic extract of propolis interferes with Streptococcus agalactiae division, promoting cytoplasm disorganization and protein synthesis inhibition.

This effect of ethanolic extract of propolis reflects its antibiotic action on Salmonella, suggesting its possible use as an alternative control of Salmonella infection.

The chemical composition of propolis from different countries has been investigated $(1,3,16)$, showing differences in its constituents and biological activities according to the local flora. Propolis from different regions of Argentina varied in chemical composition because of the distinct phytogeographical formation (13).

Based on our data, it is clear that the propolis sample from the Northeast of Brazil (Mossoró, Rio Grande do Norte State) was more efficient against Salmonella than that from the South (Urubici, Santa Catarina State), although both samples showed bactericidal activity. Further studies with isolated compounds would be important for a better understanding of this product's biological properties.

We can conclude from this assay that propolis possesses an antibacterial activity against Gram-negative bacteria that may vary according to the geographical region where the propolis was produced. 

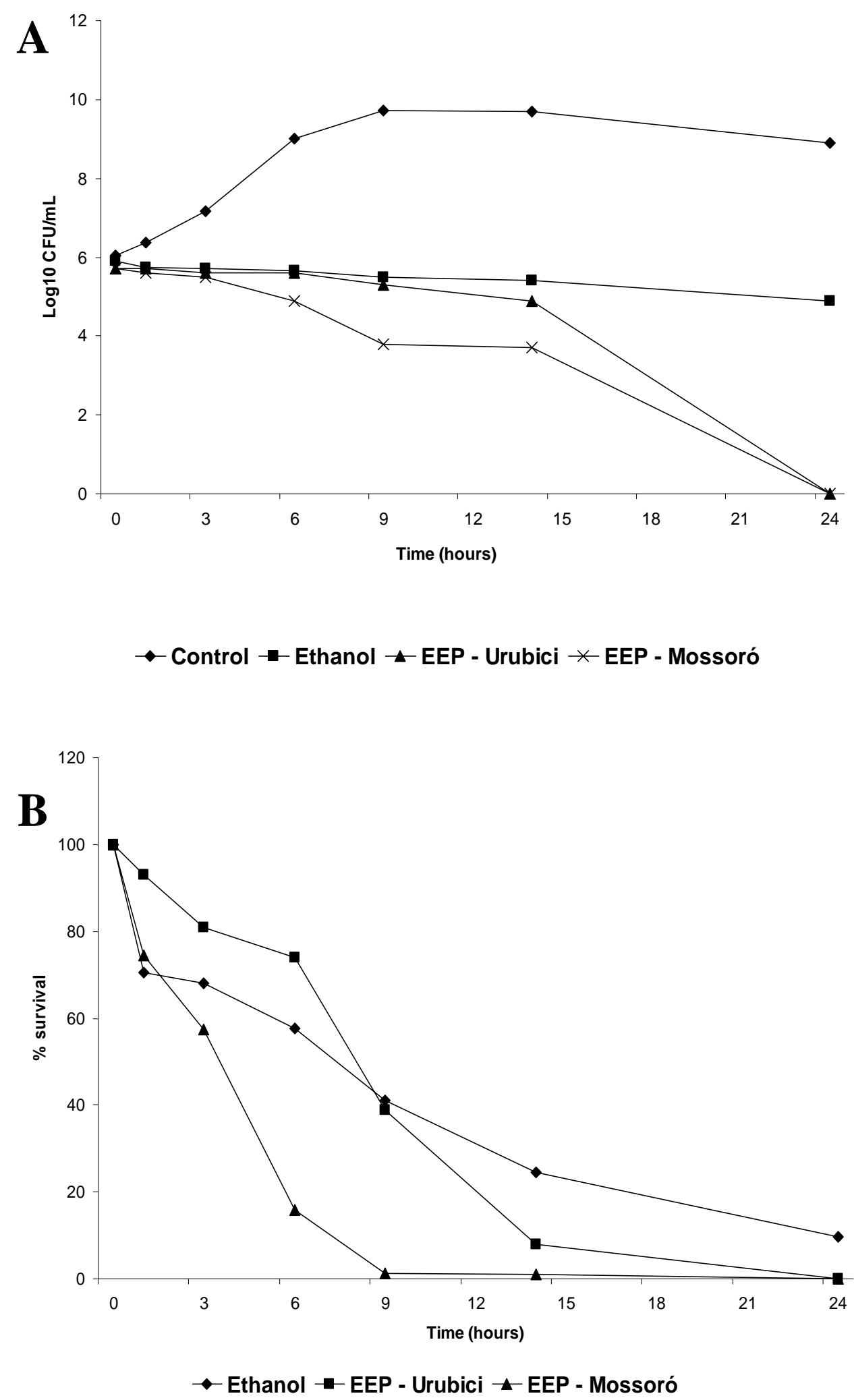

Figure 1. Profile in time of the Population Analysis (A) and Survival Curve (\%Cfu/mL) (B) of Salmonella enteritidis according to the incubation period in EEP $(10.0 \% \mathrm{v} / \mathrm{v})$ and $70 \%$ Ethanol $(12.6 \% \mathrm{v} / \mathrm{v})$.

$X^{2}=17.586 ; p<0.001$ 


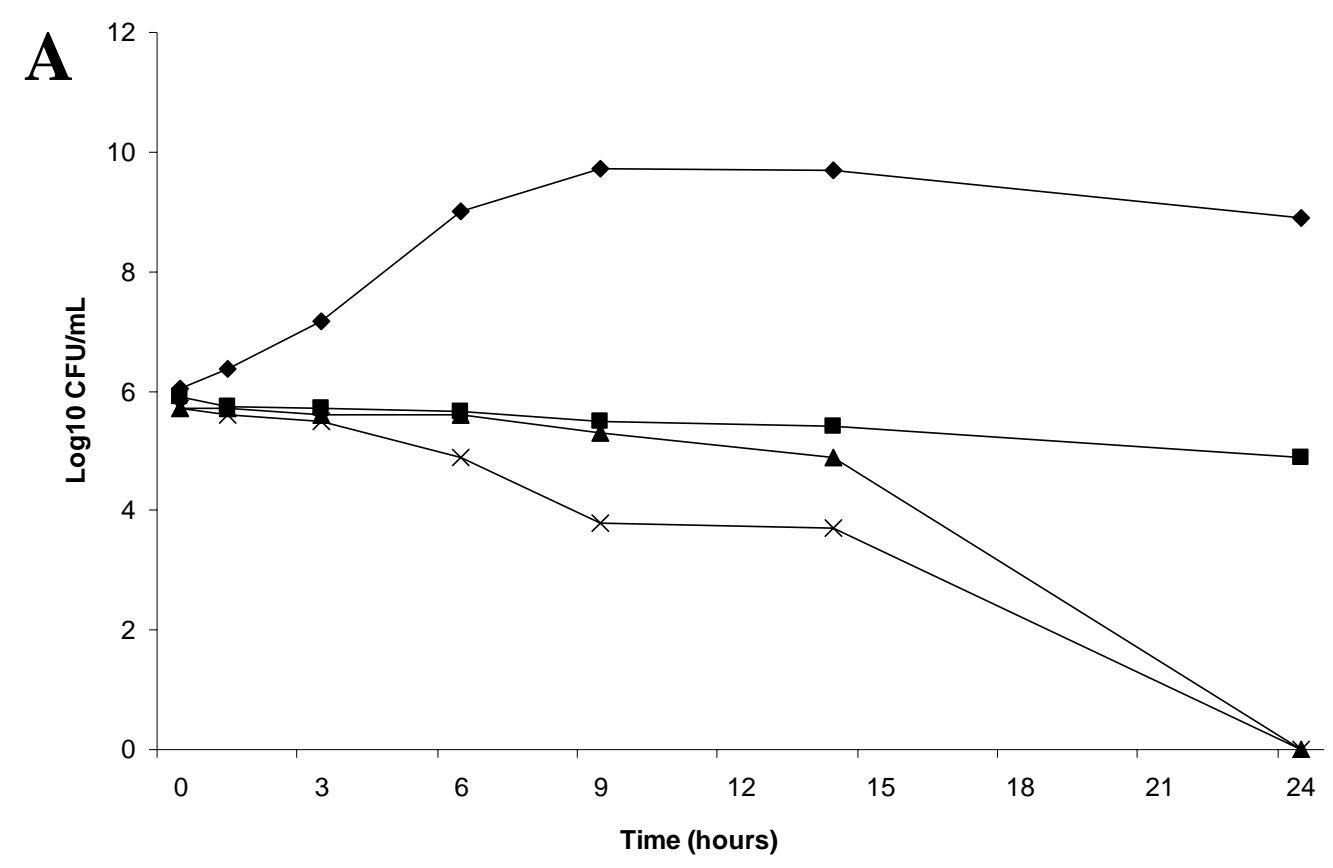

$\bullet$ Control - Ethanol \ EEP - Urubici $*$ EEP - Mossoró

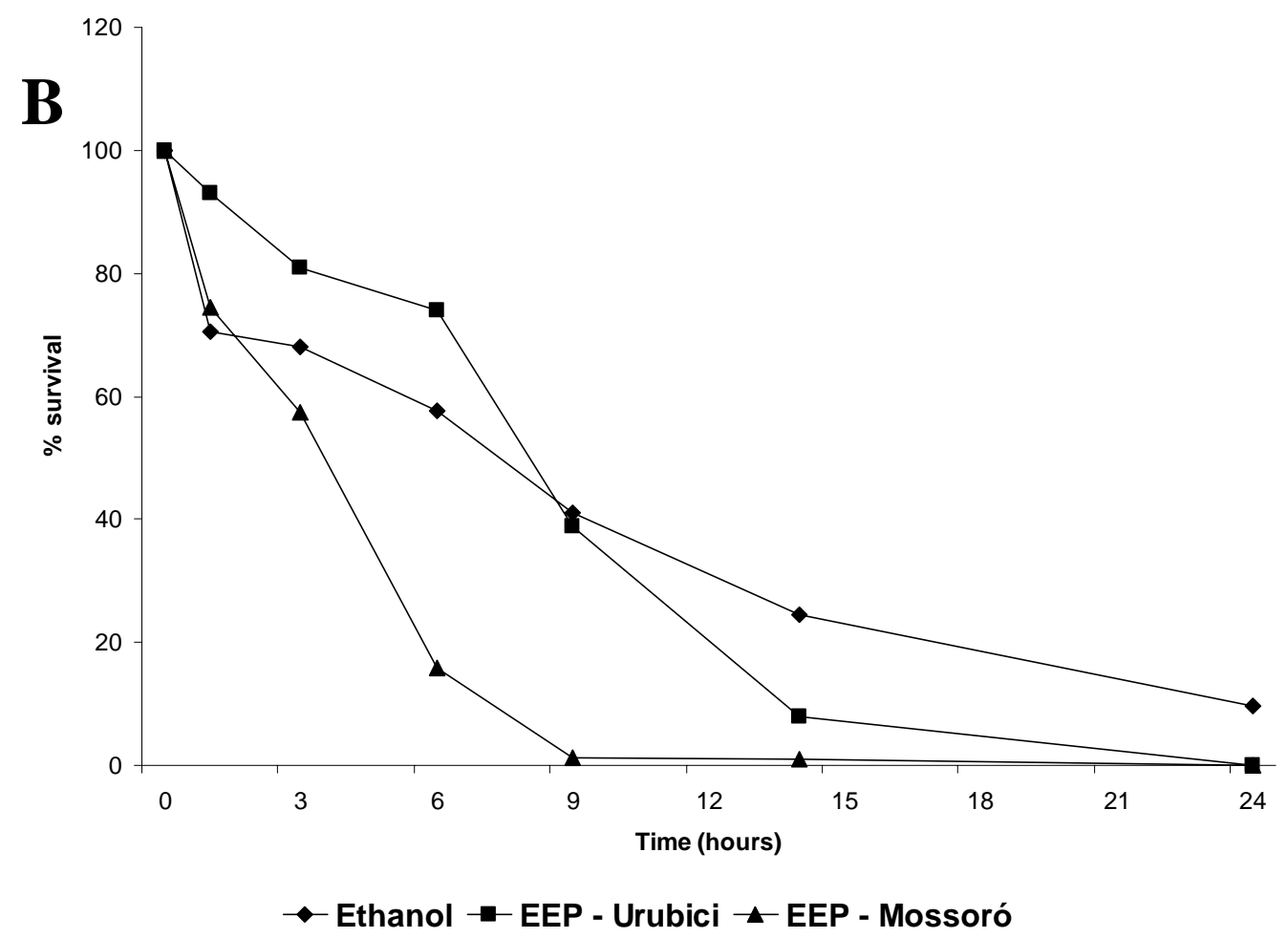

Figure 2. Profile in time of the Population Analysis $(A)$ and Survival Curve $(\% \mathrm{Cfu} / \mathrm{mL})$ (B) of Salmonella typhimurium according to the incubation period in EEP $(10.0 \% \mathrm{v} / \mathrm{v})$ and $70 \%$ Ethanol $(12.6 \% \mathrm{v} / \mathrm{v})$.

$X^{2}=20.559 ; p<0.001$ 


\section{REFERENCES}

1 BANKOVA V., BOUDOUROVA-KRASTEVA G., SFORCIN JM., FRETE X., KUJUMGIEV A., MAIMONI-RODELLA R., POPOV S. Phytochemical evidence for the plant origin of Brazilian propolis from São Paulo State. Z. Naturforsch., 1999, 54, 401-5.

2 BANSKOTA AH., TEZUKA Y., KADOTA S. Recent progress in pharmacological research of propolis. Phytotherapy Res., 2001, 15, 561-71.

3 CHRISTOV R., BANKOVA V., TSVETKOVA I., KUJUMGIEV A., TEJERA AD. Antibacterial furofuran lignans from Canary Islands propolis. Fitoterapia, 1999, 70, 89-92.

4 DOYLE MP. Reducing foodborne disease - What are the priorities? Nutr. Rev., 1993, 51, 346-7.

5 FERNANDES Jr. A., LEOMIL L., FERNANDES AAH., SFORCIN JM. The antibacterial activity of propolis produced by Apis mellifera L. and Brazilian stingless bees. J. Venom. Anim. Toxins, 2001, 7, 173-82.

6 FERNANDES Jr. A., SUGIZAKI MF., FOGO ML., FUNARI SRC., LOPES CAM. In vitro activity of propolis against bacterial and yeast pathogens isolated from human infections. J. Venom. Anim. Toxins, 1995, 1, 63-9.

7 GRANGE JM., DAVEY RW. Antibacterial properties of propolis (bee glue). J. R. Soc. Med., 1990, 83, 159-60.

8 KUJUMGIEV A., TSVETKOVA I., SERKEDJIEVA YU., BANKOVA V., CHRISTOV R., POPOV S. Antibacterial, antifungal and antiviral activity of propolis of different geographic origin. J. Ethnopharmacol., 1999, 64, 235-40.

9 MARKHAM KE., MITCHEL KA., WILKINS AL., DALDY JA., LU Y., HPLC and GCMS identification of the major organics constituent in New Zealand propolis. Phytochemistry, 1996, 42, 205-11.

10 MARTINS AMB., RIBEIRO EGA., OLIVEIRA HM., ERRERA MC., TAVECHIO AT., GELLI DS. Avaliação das condições higiênico-sanitárias de lingüiças consumidas em Ribeirão Preto/SP e Região. In: CONGRESSO BRASILEIRO DE MICROBIOLOGIA, 19, Rio de Janeiro, 1998. Abstracts... Rio de Janeiro: Congresso Brasileiro de Microbiologia, 1998. p.28. 
11 MIRZOEVA OK., GRISHANIN RN., CALDER PC. Antimicrobial action of propolis and some of its components: the effects of growth, membrane potential and mobility of bacteria. Microbiological Res., 1997, 152, 239-46.

12 NATIONAL COMMITTEE FOR CLINICAL LABORATORY STANDARDS. Methods for dilution antimicrobial susceptibility tests for bacteria that grow aerobically: approved standard. 5. ed. Wayne: NCCLS, 2000. (M100-S10/M7).

13 NIEVA MMI., ISLA MI., CUDMANI NG., VATTUONE MA., SAMPIETRO AR. Screening of antibacterial activity of Amaicha del Valle (Tucuman, Argentina) propolis. J. Ethnopharmacol., 1999, 68, 97-102.

14 SFORCIN JM., FERNANDES Jr A., LOPES CAM., BANKOVA V., FUNARI SRC. Seasonal effect on Brazilian propolis antibacterial activity. J. Ethnopharmacol., 2000, 73, 243-9.

15 TAJAISI-KIKUNI NB., SCHILCHER H. Electron microscopic and microcalorimetric investigations of the possible mechanism of the antibacterial action of a defined propolis provenance. Planta Med., 1994, 60, 222-7.

16 VALCIC S., MONTENEGRO G., MUJICA AM. Phytochemical, morphological and biological investigations of propolis from central Chile. Z. Naturforsch, 1999, 54, 406-16.

17 WAN J., KING K., CRAVEN H., McAUlleY C., TAN SE., COVENTRY MJ. Probelia PCR system for rapid detection of Salmonella in milk powder and ricotta cheese. Letters in Appl. Microbiol., 2000, 30, 267-71.

18 ZAR JH. Biostatistical analysis. 2. ed. New Jersey: Prentice Hall, 1984: 718p. 